Original Article

\title{
GC-MS ANALYSIS, HPTLC FINGERPRINT PROFILE AND DPPH FREE RADICAL SCAVENGING ASSAY OF METHANOL EXTRACT OF MARTYNIA ANNUA LINN SEEDS
}

\author{
ALI ALRABIE, OLA BASSAR, INAS AL-QADSY, MAZAHAR FAROOQUI* \\ Dr. Rafiq Zakaria College for Women, Aurangabad (M. S), India \\ Email: mazahar_64@rediffmail.com \\ Received: 26 Jan 2019 Revised and Accepted: 16 Apr 2019
}

\begin{abstract}
Objective: To investigate the photochemical constituents present in methanol extract of martynia annua seeds using Gas Chromatography-Mass Spectroscopy(GC-MS), High-Performance Thin-Layer Chromatography(HPTLC) analysis and study antioxidant activity.

Methods: Methanol extract of Martynia annua seeds were subjected to GC-MS and HPTLC analysis. HPTLC analysis was carried out using GAMAG system with a linomate5 applicator, system mobile phase (Toluene: Chloroform: Ethanol $(4: 4: 1 \mathrm{~V} / \mathrm{V} / \mathrm{V})$ ), two different volume of extract was applied $2 \mu \mathrm{l}$ and $5 \mu \mathrm{l}$. GC-MS analysis was carried out on JEOL GC MATE II, column HP 5 MS and Quadruple double focusing mass analyzer. Antioxidant activity was determined by DPPH assay.

Results: GC-MS analysis provided 17 peaks indicating the presence of seventeen different phytochemicals in methanol extract of martynia annua seeds. HPTLC fingerprint showed 6 peaks at both size $2 \mu \mathrm{l}$ and $5 \mu \mathrm{l}$ at $254 \mathrm{~nm}$ whereas 4 peaks, 9 peaks were detected at $366 \mathrm{~nm}$ for $2 \mu \mathrm{l}$ and $5 \mu \mathrm{l}$ respectively. After derivatization with $10 \%$ methanolic sulphuric acid, 8 peaks, 11 peaks were detected for $2 \mu \mathrm{l}$ and $5 \mu \mathrm{l}$ respectively when the derivatized plate was scanned at $540 \mathrm{~nm}$. DPPH free radical scavenging result showed $\mathrm{EC}_{50}$ value of $44.1 \pm 1.1 \mu \mathrm{g} / \mathrm{ml}$.
\end{abstract}

Conclusion: The GC-MS analysis showed the presence of fatty acids, ester, aldehydes and ketones whereas in HPTLC different peaks at different UVlights before and after derivatization were observed. Maximum percentage inhibition using DPPH assay was found 74 at concentration of $50 \mu \mathrm{g} / \mathrm{ml}$.

Keywords: Martynia annua, GC-MS, HPTLC fingerprint, Antioxidant activity

(C) 2019 The Authors. Published by Innovare Academic Sciences Pvt Ltd. This is an open access article under the CC BY license (http://creativecommons.org/licenses/by/4.0/) DOI: http://dx.doi.org/10.22159/ijpps.2019v11i6.32206

\section{INTRODUCTION}

The goals of using plants as source of therapeutic agents not only to use the hole plant or part of it as a herbal remedy but also the bioactive compounds can be isolated from the plant for direct use as drugs, to use agents as pharmacological tools, to produce bioactive compounds of new or known structures as model compounds for semi-synthesis to synthesis patentable entities of higher activity and/or lower toxicity [1]. India is one of the richest in the world in the medicinal plant, has six of the system of medicine (Ayurveda, Siddha, Unani and Yoga, Naturopathy and Homoeopathy) [2]. Martynia annua belong to Martyniaceae family [3], it is known as Devil's Claw [4]. It is from Mexico natively [5] and found in throughout India [6]. Martynia annua seed is black; the most biologically active parts in this plant are leaves and seeds. Seeds are used in inflammation and considered alexiteric [7]. Due to growing condition of medicinal plants such as climate, harvest season, soil fertility, the drying process, etc, there are considerable qualitative and quantitative differences between chemical constituents of the plant and therefore in its therapeutic effect $[8,9]$. Nowadays the demand of herbal drugs for primary healthcare is increasing due to their safety, efficacy and rarely have side effect [10]. The pharmaceutical industries focus in investigation of higher plants as a source for novel lead structure as well as for the development of standardized phototherapeutic agents [11]. Standardization of plant material is need of the day [12] but the standardization and quality control of herbal drugs is very complicated due to variation of phytoconstituents within the same plant or from part to part of same plant [13]. Modern chromatographic techniques such as GCMS and HPTLC fingerprint play an important role for identification, quantification of the chemical composition of plant material and may be useful for proper standardization of herbal drug formulation [14-16]. The aim of this study was to investigate the phytochemical constituents present in methanol extract of martynia annua seeds using GC-MS and HPTLC analysis and evaluation of antioxidant activity using DPPH assay.

\section{MATERIALS AND METHODS}

\section{Chemicals and regents}

1,1-Diphenyl-2-picrylhydrazyl radical(DPPH) was purchased from sigma-aldrish (USA), Ascorbic aid and butylated hydroxytoluene (BHT) were purchased from SDF (Mumbai). All of the other reagents were analytical grade.

\section{Plant material collection}

Martynia апnиа seeds were purchased from local venderAurangabad. It was authentication by Dr. Narayan Pandura Department of botany Dr. Babaseab Ambedkar Marathwada University-Aurangabad. Plant seeds were washed, dried in shadow at room temperature for more than $20 \mathrm{~d}$, ground into powder form and kept in an airtight container in dark place until the time of use.

\section{Preparation of extract}

$50 \mathrm{mg}$ of dried martynia annua seeds powder was extracted with 95\% methanol ( $500 \mathrm{ml}$ ) by using Soxhlet apparatus for $6 \mathrm{~h}$. After extraction, the solvent was removed using rotary vacuum evaporator; free solvent extract was kept in amber bottle in refrigerator.

\section{Gas chromatography-mass spectroscopy (GC-MS)}

GS-MS analysis of methanol extract of martynia annua seeds was carried out in Indian Institute of Technology (IIT)-Madras. GC-MS analysis was done by using JEOL GC MATE II (GC model) equipped with HP 5 MS column. High pure helium as carrier gas at a constant flow rate of $1 \mathrm{ml} / \mathrm{min}$ was used for GC separation. Injector temperature was set at $220^{\circ} \mathrm{C}$ and Oven temperature was set as 50 ${ }^{\circ} \mathrm{C}$ raised to $250{ }^{\circ} \mathrm{C}$ at $10^{\circ} \mathrm{C} / \mathrm{min}$. Total GC running time was $30 \mathrm{~min}$.

High sensitive quadruple double focusing mass analyzer was used and equipped with photon multiplier tube as the detector; mass range of 50 to $600 \mathrm{amu}$; and ionization voltage (Electron impact ionization) $70 \mathrm{eV}$ was used. 


\section{High performance thin-layer chromatography (HPTLC)}

HPTLC study was reformed by following Reich and Schibli guidelines [17].

\section{Sample application}

The plant extract was dissolved in chromatographic grade methanol, two and five $\mu \mathrm{l}$ of extract solution individually was loaded as $8 \mathrm{~mm}$ band length in the plate format $200 \mathrm{ml} \times 100 \mathrm{~mm}$ Merck, TLC plate's silica gel $60 \mathrm{~F}_{254}$ using LINOMAT 5 applicator attached to CAMAG HPTLC system which was programmed through winCAT software, version 2.5.18053.1

\section{Spot development}

After the application of sample, the chromatogram was developed in twin Trough Chamber (TTC) $20 \times 10 \mathrm{~cm}$ which saturated with mobile phase Toluene: Chloroform: Ethanol $(4: 4: 1 \mathrm{~V} / \mathrm{V} / \mathrm{V})$, saturated time $20 \mathrm{~min}$. After development, the plate was dried at room temperature for $5 \mathrm{~min}$.

\section{Photo-documentation}

The plate In Photo-Documentation under GLP (Camag Visualiser), images were captured at white light, UV $254 \mathrm{~nm}$ and UV $366 \mathrm{~nm}$

\section{Scanning}

The plate was fixed in CAMAG TLC Scanner 4 and scanning was done at UV $254 \mathrm{~nm}$ (Absorption, Lamp: Deuterium, Filter: K320) and UV $366 \mathrm{~nm}$ (Fluorescence, Lamp: Mercury, filter: K400).

\section{Derivatization}

The developed plate was immersed in immersion device which contains $10 \%$ methanolic sulphuric acid with dipping speed $5 \mathrm{~mm} / \mathrm{sec}$., the derivatized plate was heated at $100{ }^{\circ} \mathrm{C}$ for $3 \mathrm{~min}$, the plate was photodocumented in white light and $366 \mathrm{~nm}$. The scanning for a derivatized plate was done at $540 \mathrm{~nm}$ (Absorption, Lamp: Tungsten).

\section{DPPH free radical scavenging assay}

The antioxidant activity of the extract was determined using 1, 1Diphenyl-2-picrylhydrazyl radical (DPPH). DPPH scavenging activity was measured by the spectrophotometric method with minor modification (Sreejayan and Rao, 1996) [18]. $0.05 \mathrm{ml}$ of the extract dissolved in DMSO were diluted to $1.0 \mathrm{ml}$ using (ethanol) to attain the concentrations $10-50 \mu \mathrm{g} / \mathrm{ml}$, and were added with DPPH $(200$ $\mu \mathrm{M}$, prepared in $95 \%$ ethanol). An equal amount of DMSO+ethanol was added to the control. All the tests were performed using triplicate aliquots. The decrease in the absorbance of test compounds was read at $515 \mathrm{~nm}$ after 20 min incubation in dark using spectrophotometer (Shimadzu UV-1800) and the percentage inhibition was calculated by using the formula:

$$
\% \text { scavenging activity }=\frac{A-B}{(A)} \times 100
$$

Where $\mathrm{A}$ is a control absorbance $=$ the measurement of DPPH solution without extract while $\mathrm{B}$ is a sample absorbance $=$ the measurement of DPPH solution with the extract. Ascorbic acid and butylated hydroxytoluene (BHT) were used as standard drugs.

\section{Statistical analysis}

Antioxidant activity (DPPH assay) of methanol extract of martynia annua seeds were performed in triplicate $(n=3)$. The presented results were mean $\pm \mathrm{SE}$ (Standard Error). For calculation of $\mathrm{EC}_{50}$, the data were analyzed by Non Linear Regression followed by effector v/s response analysis on Graphpad Prism 5.0.

\section{RESULTS AND DISCUSSION}

GC-MS: The GC-MS chromatogram is shown in fig. 1. As it is difficult to find out or isolate individual component in their purest form, the chromatogram can be used as a fingerprint for the identification of the herbal drug. The different phytochemicals corresponding to different retention time can be predicted and hence these are enlisted in table 1 . The higher fatty acids and their esters are dominating. Hence this extract can be a good surfactant which helps to reduce the surface tension of the solvent. GC-MS chromatogram of methanol extract of martynia annua seeds (fig. 1) shows 17 peaks, indicating the presence of 17 phytoconstituents. RT value, peak area, peak area \%, molecular formula and compound name of each peak was shown in table 1.

Table 1: Phytochemicals compounds identified in methanol extract of martynia annua seeds

\begin{tabular}{lllllll}
\hline & RT(min) & $\begin{array}{l}\text { Peak } \\
\text { area }\end{array}$ & Peak area \% & Peak height & Molecular formula & Compound name \\
\hline 1 & 3.48 & 8798052 & 1.25 & 439367 & $\mathrm{C}_{4} \mathrm{H}_{7} \mathrm{NS}$ & Thiazole, 4,5-dihydro-2-methyl- \\
2 & 9.47 & 17583168 & 2.5 & 759620 & $\mathrm{C}_{6} \mathrm{H}_{12} \mathrm{O}_{2}$ & 4-hydroxy-3-hexanone \\
3 & 10.5 & 14658873 & 2.08 & 769046 & $\mathrm{C}_{10} \mathrm{H}_{14} \mathrm{O}$ & 3.5-Heptadienal,2-ethylidene-6-methyl- \\
4 & 11.68 & 21532196 & 3.06 & 1114019 & $\mathrm{C}_{10} \mathrm{H}_{10} \mathrm{~N}_{2}$ & 1H-Pyrazole,1-methyl-3-phenyl- \\
5 & 12.15 & 26220488 & 3.72 & 1674195 & $\mathrm{C}_{15} \mathrm{H}_{32}$ & Pentadecane \\
6 & 12.38 & 28780778 & 4.08 & 1262519 & $\mathrm{C}_{15} \mathrm{H}_{24} \mathrm{O}$ & 2,6,10-trimetyl-12-oxatricyclo[7,3,1,0(1,6)]tridec-2-ene \\
7 & 13.67 & 36055692 & 5.12 & 2756467 & $\mathrm{C}_{16} \mathrm{H}_{22} \mathrm{O}$ & Cycloisolongifolene,8,9-dehydro-9-formyl- \\
8 & 13.97 & 40451350 & 5.74 & 1640731 & $\mathrm{C}_{15} \mathrm{H}_{10} \mathrm{O}_{2}$ & Flavone \\
9 & 15.62 & 40906514 & 5.80 & 2632072 & $\mathrm{C}_{12} \mathrm{H}_{14} \mathrm{O}_{3}$ & 2-Propenoic acid,3-[4-methoxyphenyl]-, ethyl ester \\
10 & 16.77 & 40309114 & 5.72 & 1677498 & $\mathrm{C}_{16} \mathrm{H}_{28} \mathrm{O}$ & 2,6,10-Dodecatriene,3[E],7[E],11-trimethyl-1-methoxy- \\
11 & 17.02 & 41343040 & 5.87 & 3292430 & $\mathrm{C}_{17} \mathrm{H}_{34} \mathrm{O}_{2}$ & Hexadecanoic acid, methyl ester- \\
12 & 18.05 & 76337075 & 10.83 & 3251117 & $\mathrm{C}_{16} \mathrm{H}_{32} \mathrm{O}_{2}$ & Palmitic acid \\
13 & 18.68 & 68868881 & 9.77 & 3451975 & $\mathrm{C}_{19} \mathrm{H}_{34} \mathrm{O}_{2}$ & 8,11-Octadecadienoic acid, methyl ester \\
14 & 19.53 & 80905437 & 11.48 & 3408908 & $\mathrm{C}_{19} \mathrm{H}_{36} \mathrm{O}$ & 12-Methyl-E,E-2,13-octadecadien-1-ol \\
15 & 20.67 & 55785668 & 7.92 & 3282854 & $\mathrm{C}_{18} \mathrm{H}_{32} \mathrm{O}_{2}$ & $9,12-0 c t a d e c a d i e n o i c ~ a c i d[Z, Z]-$ \\
16 & 23.17 & 57618947 & 8.18 & 2430096 & $\mathrm{C}_{21} \mathrm{H}_{38} \mathrm{O}_{2}$ & Isopropyl linoleate \\
17 & 25.47 & 46995620 & 6.67 & 2103695 & $\mathrm{C}_{21} \mathrm{H}_{38} \mathrm{O}_{4}$ & 9,12-Octadecadienoic acid,[Z,Z]-,2,3-dihydroxypropyl ester \\
\hline
\end{tabular}

GC-MS result showed that the first major percentage compound was 12-Methyl-E,E-2,13-octadecadien-1-ol (11.48\%) which have been reported to have anticonvulsant, antibacterial, antihistaminic, anesthetic, antioxidant, allergenic, anagelsic, antiseptic, and antisalmonella activity [19]. The second major percentage compound was Palmitic acid $(10.83 \%)$ which possesses antimicrobial, antiinflammatory, antiandrogenic flavor, antioxidant, 5-Alpha-reductase inhibitor, hypocholesterolemic, hemolytic, nematicide, potent mosquito larvicide, and pesticide activity [20, 21]. Third major percentage compound was 8,11-Octadecadienoic acid, methyl ester $(9.77 \%)$ which have no biological activity reported. Isopropyl linoleate was the fourth major compound with peak area percentage of $8.18 \%$, it possesses antioxidant, antimicrobial, and anticancer activity [22]. The fifth major percentage compound was 9,12Octadecadienoic acid[Z,Z]-(7.92\%) which have been reported to have anti-inflammatory, anti-adherent vegetable, and nematicide activity [23, 24]. 9,12-Octadecadienoic acid,[Z,Z]-,2,3-dihydroxypropyl ester possesses antieczemic, hypocholesterolemic, 
nematicide, and hepatoprotective [25]. 9,12-Octadecadienoic acid,[Z,Z]-,2,3-dihydroxypropyl ester is fatty acid and have been reported to have antioxidant, antimicrobial activity [26]. Some of minor percentage compounds have been reported to have biological activities such as 2-Propenoic acid, 3-[4-methoxyphenyl]-, ethyl ester possesses antimicrobial activity [27]; Flavone possesses antioxidant, hypocholesterolemic, and androgenic activity [28]; Pentadecane has antioxidant and antibacterial activity [29]. GC-MS result showed that the martynia annua seeds contain bioactive compounds that have medical importance like antioxidant activity.

GC-MS result showed the presence of seven of Fatty acids or their esters: 2-Propenoic acid,3-[4-methoxyphenyl]-,ethyl ester(5.80\%), Hexadecanoic acid, methyl ester (5.87\%), Palmetic acid (10.83\%),
8,11-Octadecadienoic acid, methyl ester (9.77\%), 9,12Octadecadienoic acid [Z,Z]-(7.92\%), Isopropyl linoleate $(8.18 \%)$, 9,12-Octadecadienoic acid,[Z,Z]-, 2,3-dihydroxypropyl ester (6.67\%) with retention time 15.62, 17.02, 18.05, 18.68, 20.67, 23.17 and 25.47 respectively.

\section{HPTLC}

The various HPTLC chromatograms at different sample size $(2 \mu \mathrm{l}$ and 5 $\mu \mathrm{l})$ and at a different wavelength (254 $\mathrm{nm}$ and $366 \mathrm{~nm}$ ) and after derivatization $(540 \mathrm{~nm})$ have been shown in fig. 2 to 9 . Initially, the HPTLC developed plate was photo-documented at white light, at $254 \mathrm{~nm}$ and $366 \mathrm{~nm}$ (fig. 2) and scanned at $254 \mathrm{~nm}$ and $366 \mathrm{~nm}$. The plates were derivatized using $10 \%$ methanolic sulphuric acid and photodocumented at white light and at $366 \mathrm{~nm}$ (fig. 3) and scanned at $540 \mathrm{~nm}$.

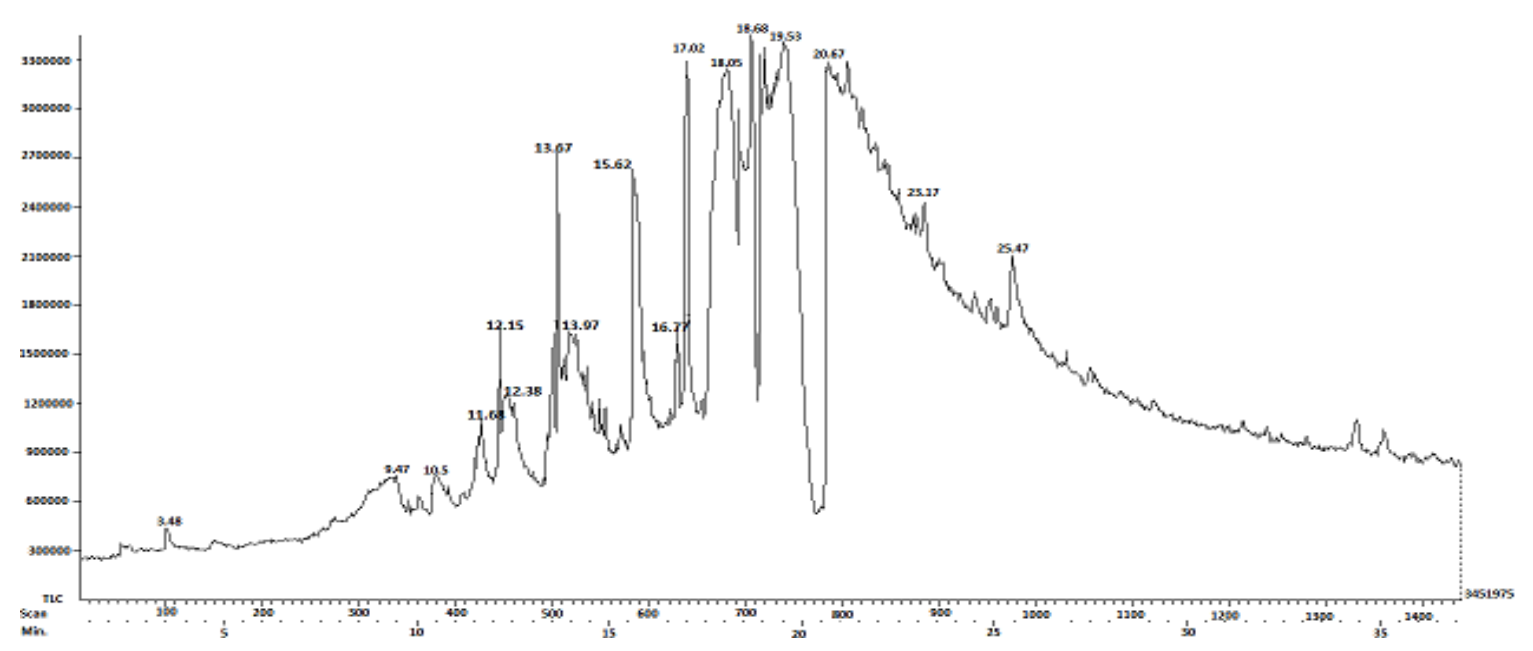

Fig. 1: GC MS chromatogram of methanol extract of martynia annua seeds

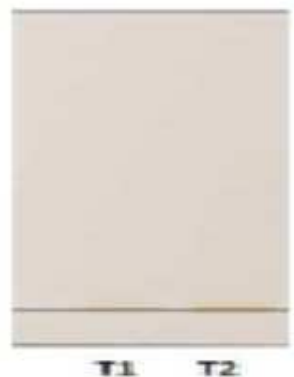

(a) Wight light

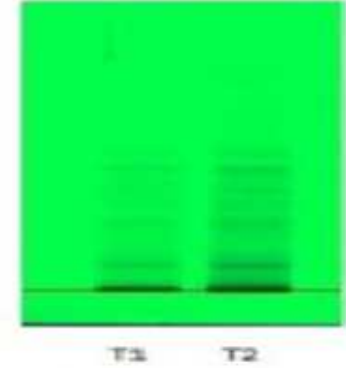

urv $2 \mathrm{asm}$

(b) $254 \mathrm{~nm}$

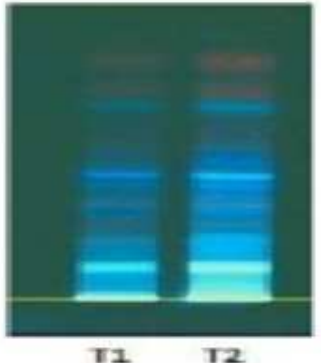

(c) $366 \mathrm{~nm}$

Fig. 2: HPTLC chromatogram (a) white light (b) at $254 \mathrm{~nm}$ (c) at $366 \mathrm{~nm}$ for different size T1: $2 \mu \mathrm{l}$, T2: $5 \mu \mathrm{l}$

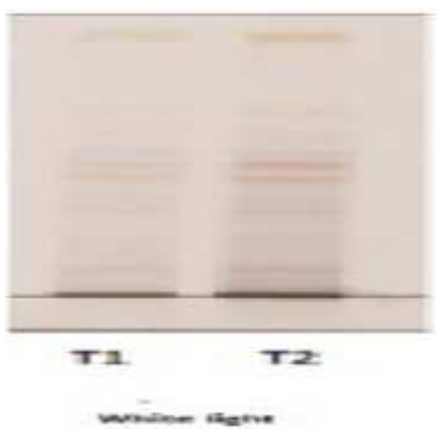

(a) White light

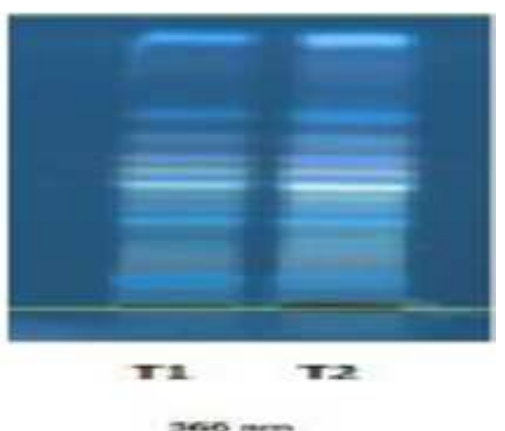

(b) $366 \mathrm{~nm}$

Fig. 3: HPTLC chromatogram after derivatization (a) white light (b) at $366 \mathrm{~nm}$ for different size T1: $2 \mu \mathrm{l}$, T2:5 $\mu \mathrm{l}$ 
For $2 \mu \mathrm{l}$ sample size, six peaks were detected and the highest peak area $28.10 \%$ appears at $\mathrm{R}_{\mathrm{f}}=0.105$ when the developed plate was scanned at $254 \mathrm{~nm}$, but at the UV wavelength $366 \mathrm{~nm}$, the number of peaks reduced to four and highest area $(62.70 \%)$ covered at peak maxima $R_{f}=0.123$. After derivatization, the number of peaks increases to eight and highest peak get shifted to $\mathrm{R}_{\mathrm{f}}=0.426$ with percentage area $=23.21 \%$ (table 2 ).
When the sample size is increased to $5 \mu \mathrm{l}$, the highest peak area (25.01\%) appears at $\mathrm{R}_{\mathrm{f}}=0.439$ for $254 \mathrm{~nm}$. When developed plate scanned at $366 \mathrm{~nm}$, the number of peaks observed to be nine and at $\mathrm{R}_{\mathrm{f}}=$ 0.126 highest peak area (48.33\%) observed. After derivatization and derivatized plate scanned at $540 \mathrm{~nm}$, the number of peaks increased to eleven with highest peak area (26.72\%) at $\mathrm{R}_{\mathrm{f}}=0.473$.

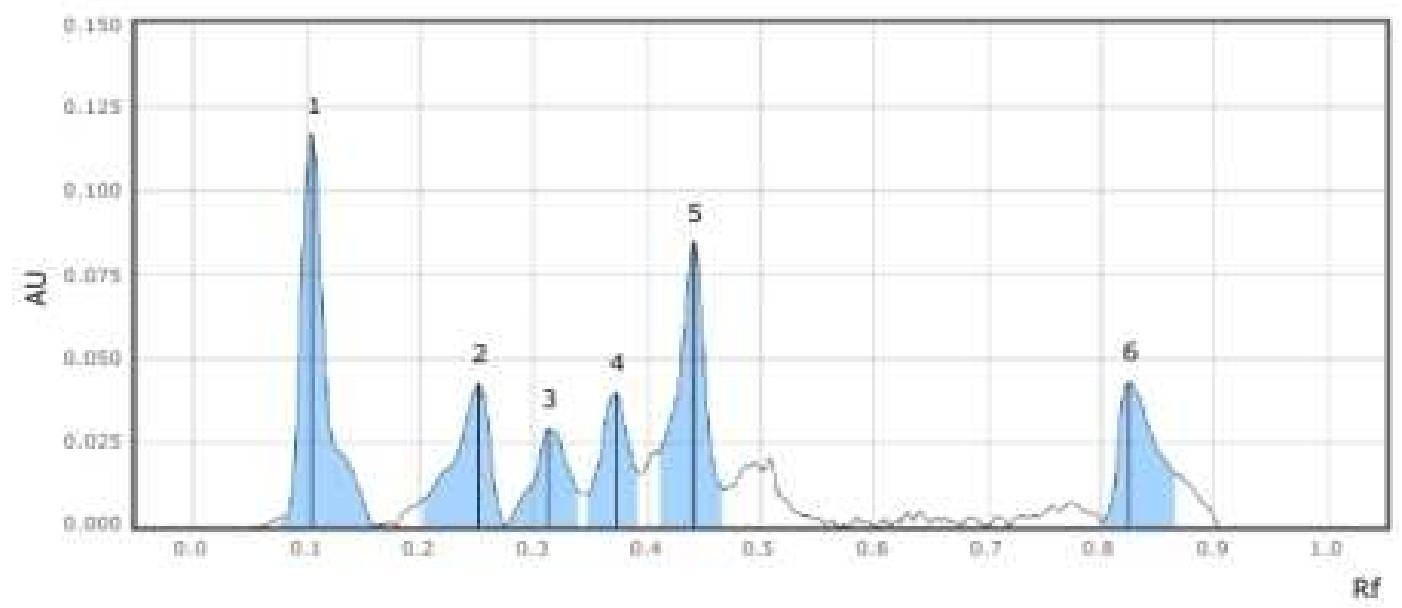

Fig. 4: HPTLC densitometric chromatogram at $254 \mathrm{~nm}$, size T1: $2 \mu \mathrm{l}$

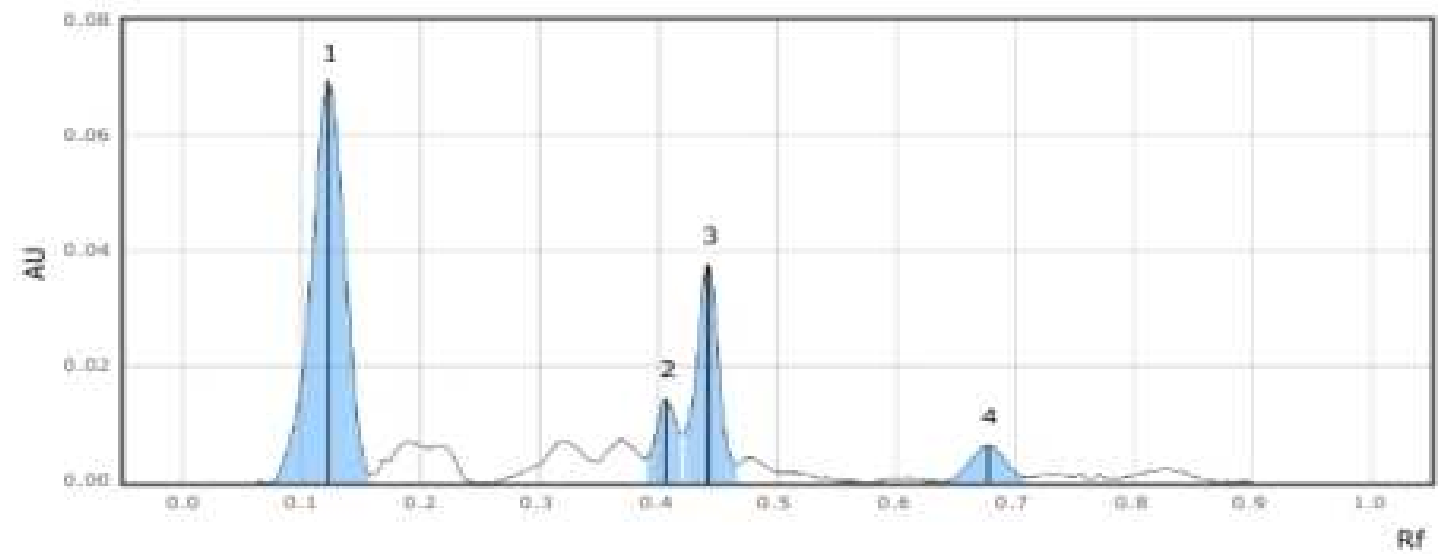

Fig. 5: HPTLC densitometric chromatogram at $366 \mathrm{~nm}$, size T1: $2 \mu \mathrm{l}$

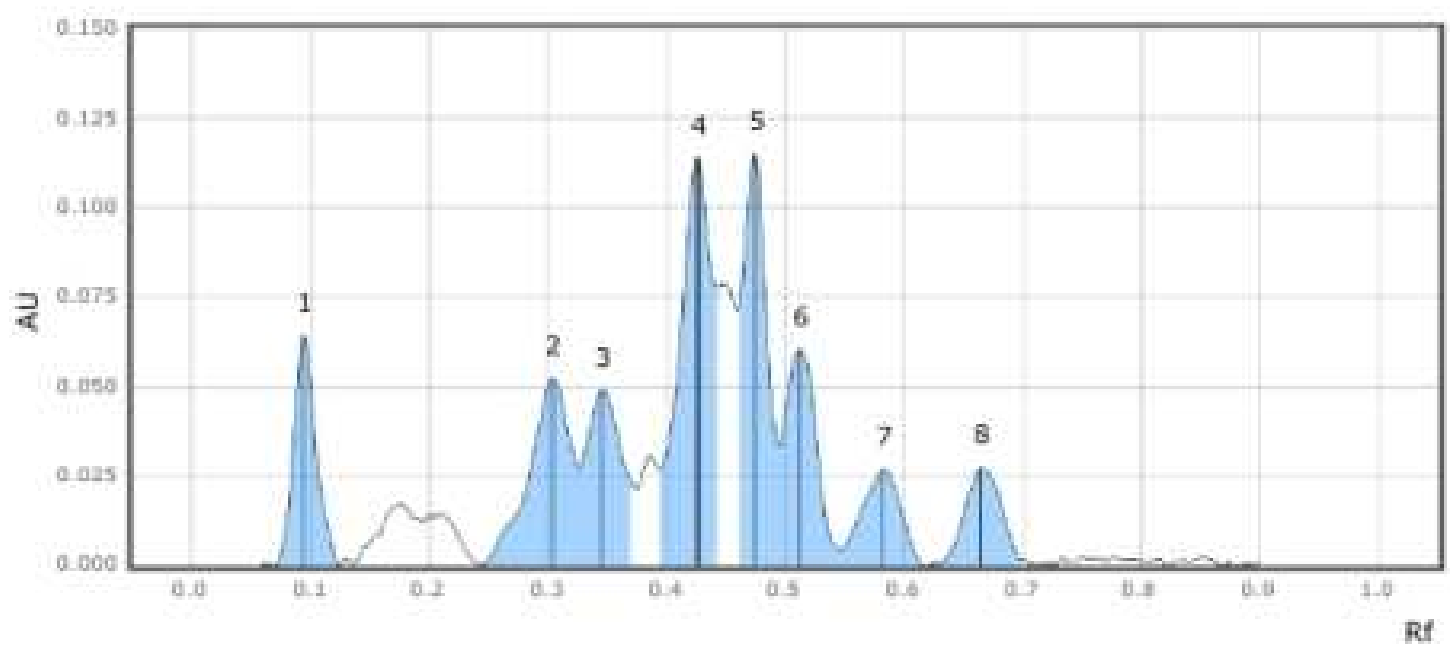

Fig. 6: HPTLC densitometric chromatogram (after derivatization) at $540 \mathrm{~nm}$, size T1:2 $\mu \mathrm{l}$ 
Table 2: Rfvalues and area \% of HPTLC chromatogram of methanol extract of martynia annua seeds, size: $2 \boldsymbol{\mu l}$

\begin{tabular}{|c|c|c|c|c|c|c|}
\hline \multirow[t]{2}{*}{ Peak no. } & \multicolumn{2}{|l|}{$254 \mathrm{~nm}$} & \multicolumn{2}{|l|}{$366 \mathrm{~nm}$} & \multicolumn{2}{|c|}{$540 \mathrm{~nm}$ (after derivatization) } \\
\hline & $\left(R_{f}\right) \max$ & Area \% & $\left(R_{f}\right) \max$ & Area \% & $\left(R_{f}\right) \max$ & Area \% \\
\hline 1 & 0.105 & 28.10 & 0.123 & 62.70 & 0.094 & 9.01 \\
\hline 2 & 0.252 & 13.99 & 0.406 & 8.34 & 0.303 & 13.68 \\
\hline 3 & 0.313 & 9.74 & 0.442 & 22.94 & 0.345 & 11.20 \\
\hline 4 & 0.373 & 10.91 & 0.677 & 6.01 & 0.426 & 23.21 \\
\hline 5 & 0.440 & 22.29 & & & 0.474 & 17.68 \\
\hline 6 & 0.824 & 14.97 & & & 0.511 & 12.25 \\
\hline 7 & & & & & 0.582 & 6.64 \\
\hline 8 & & & & & 0.665 & 6.33 \\
\hline
\end{tabular}

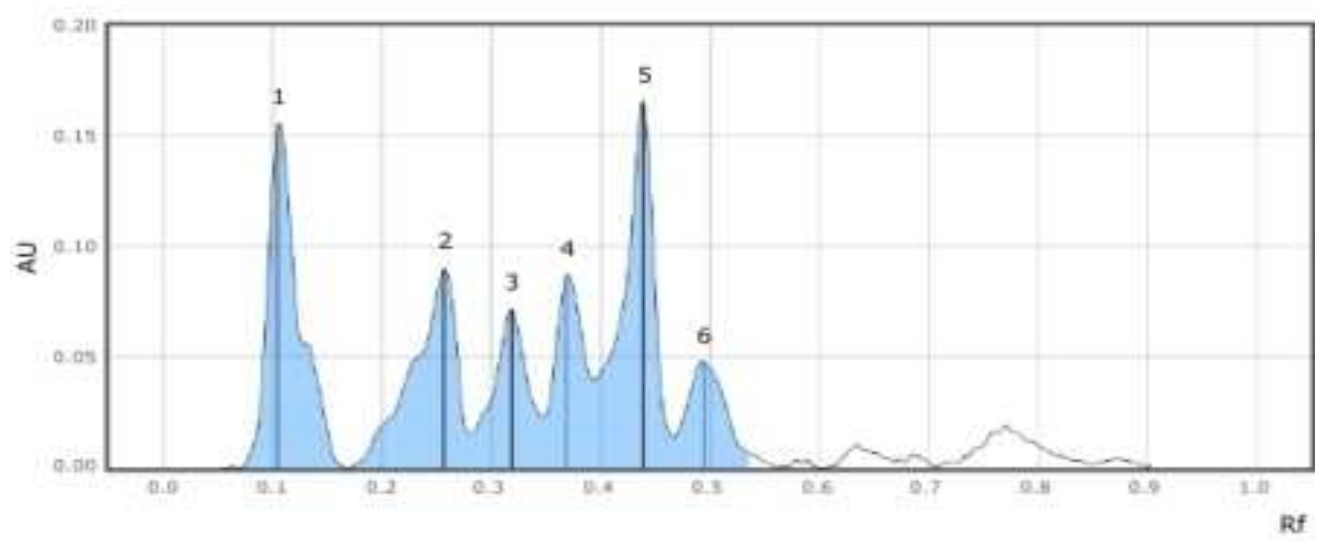

Fig. 7: HPTLC densitometric chromatogram at $254 \mathrm{~nm}$, size: $5 \mu \mathrm{l}$

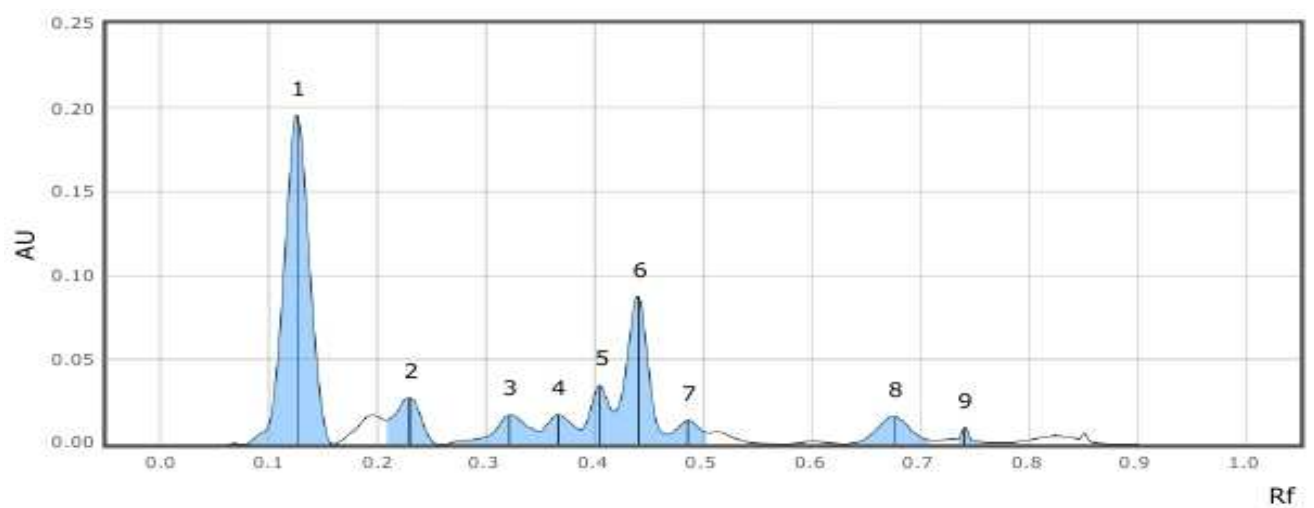

Fig. 8: HPTLC densitometric chromatogram at $366 \mathrm{~nm}$, size: $5 \mu \mathrm{l}$

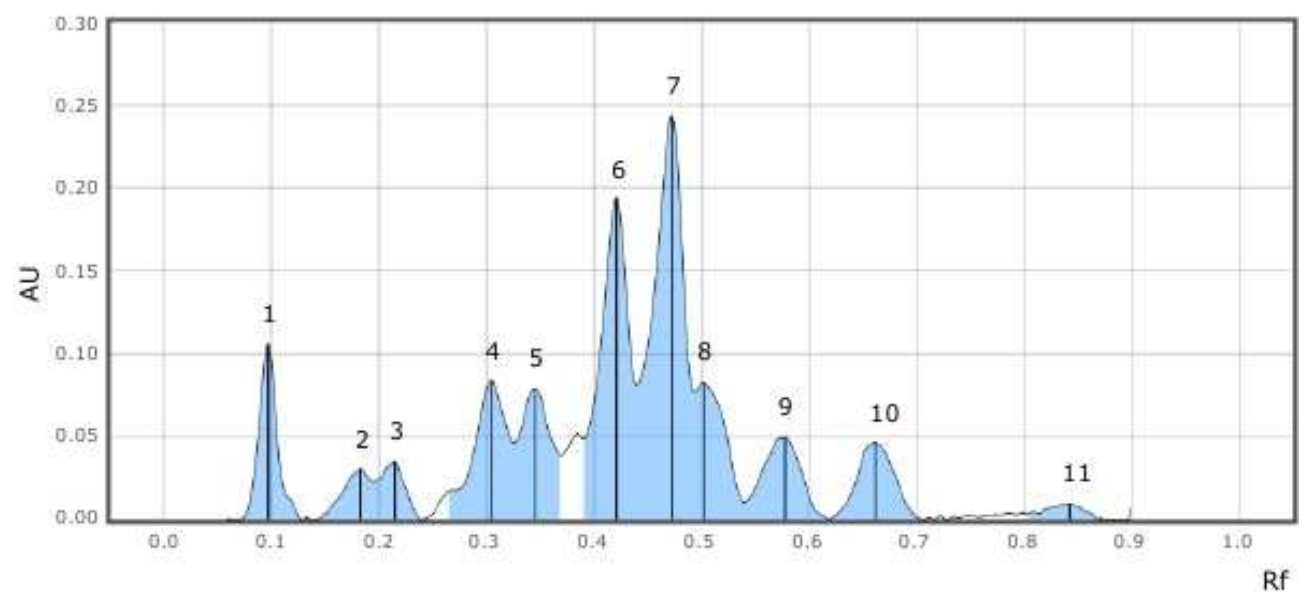

Fig. 9: HPTLC densitometric chromatogram (after derivatization) at $540 \mathrm{~nm}$, size: $5 \mu \mathrm{l}$ 
Table 3: $\mathbf{R}_{\mathrm{f}}$ values and area \% of HPTLC chromatogram of methanol extract of martynia annua seeds, size: $5 \boldsymbol{\mu l}$

\begin{tabular}{|c|c|c|c|c|c|c|}
\hline \multirow{2}{*}{$\begin{array}{l}\text { Peak } \\
\text { No. }\end{array}$} & \multicolumn{2}{|l|}{$254 \mathrm{~nm}$} & \multicolumn{2}{|l|}{$366 \mathrm{~nm}$} & \multicolumn{2}{|c|}{$540 \mathrm{~nm}$ (after derivatization) } \\
\hline & $\mathbf{R}_{\mathrm{f}} \max$ & Area \% & $\mathbf{R}_{\mathrm{f}} \max$ & Area \% & $\mathbf{R}_{\mathrm{f}} \max$ & Area \% \\
\hline 1 & 0.105 & 23.38 & 0.126 & 48.33 & 0.097 & 6.85 \\
\hline 2 & 0.256 & 18.64 & 0.229 & 6.97 & 0.182 & 2.87 \\
\hline 3 & 0.318 & 11.87 & 0.321 & 5.67 & 0.215 & 3.21 \\
\hline 4 & 0.369 & 12.17 & 0.366 & 4.50 & 0.305 & 9.64 \\
\hline 5 & 0.439 & 25.01 & 0.405 & 6.23 & 0.345 & 8.62 \\
\hline 6 & 0.494 & 8.93 & 0.440 & 18.64 & 0.421 & 19.30 \\
\hline 7 & & & 0.485 & 3.44 & 0.473 & 26.72 \\
\hline 8 & & & 0.676 & 5.31 & 0.502 & 8.59 \\
\hline 9 & & & 0.740 & 0.90 & 0.577 & 6.85 \\
\hline 10 & & & & & 0.661 & 6.10 \\
\hline 11 & & & & & 0.842 & 1.25 \\
\hline
\end{tabular}

\section{DPPH free radical scavenging assay}

Fig. 10 showed the DPPH scavenging activity of various concentrations methanol extract of martynia annua seeds. Increase extract concentration leads to increase antioxidant activity (DPPH scavenging activity) and maximum percentage inhibition was found in the extract has $50 \mu \mathrm{g} / \mathrm{ml}$ concentration. $\mathrm{EC}_{50}$ is a concentration of drug or extract required to obtain a $50 \%$ antioxidant effect. Table 4 showed $\mathrm{EC}_{50}$ values of methanol extract of martynia annua seeds and two standard drugs: ascorbic acid and BHT (butylated hydroxytoluene). Lowest EC 50 value means highest antioxidant activity.

Sample which have $\mathrm{EC}_{50}$ lower than $50 \mu \mathrm{g} / \mathrm{ml}$, is a very strong antioxidant, and $50-100 \mu \mathrm{g} / \mathrm{ml}$ is a strong antioxidant, and $101-150$ $\mu \mathrm{g} / \mathrm{ml}$ is a medium antioxidant while a weak antioxidant with $\mathrm{EC}_{50}>150 \mu \mathrm{g} / \mathrm{ml}[30] . \mathrm{EC}_{50}$ value of extract was found $44.1 \pm 1.1 \mu \mathrm{g} / \mathrm{ml}$ while $\mathrm{EC}_{50}$ of ascorbic acid and BHT were found $11.5 \pm 0.6 \mu \mathrm{g} / \mathrm{ml}$ and $12.7 \pm 0.4 \mu \mathrm{g} / \mathrm{ml}$ respectively.

Table 4: $\mathrm{EC}_{50}$ value of DPPH free radical scavenging of extract

\begin{tabular}{lc}
\hline $\mathbf{E C}_{50} \boldsymbol{\mu g} / \mathbf{m l}$ & \\
\hline Ascorbic acid(standard) & $11.5 \pm 0.6$ \\
BHT(standard) & $12.7 \pm 0.4$ \\
Martynia annua extract & $44.1 \pm 1.1$ \\
\hline
\end{tabular}

Values were obtained as mean \pm SE (Standard Error), $n=3$.

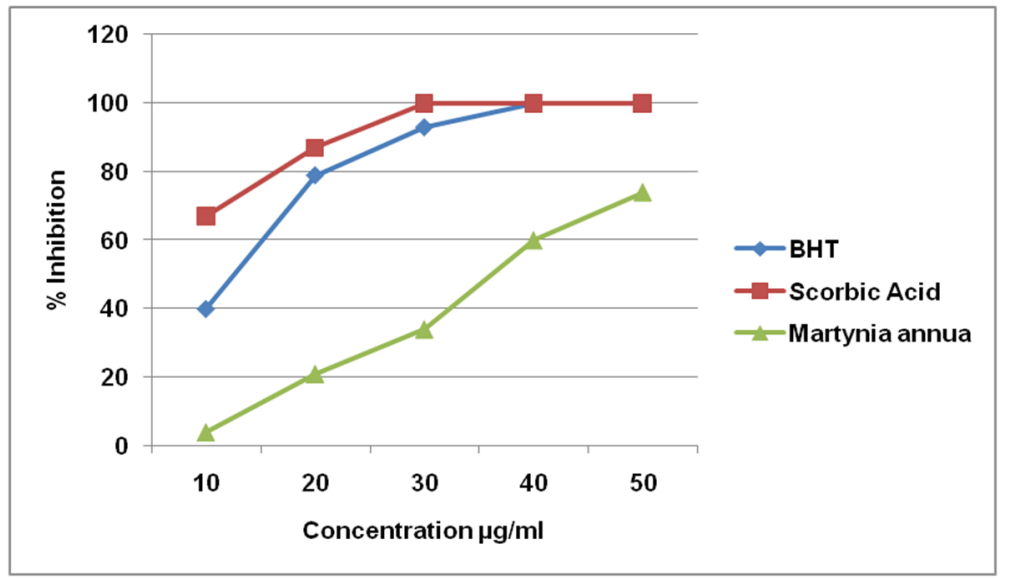

Fig. 10: DPPH radical scavenging activity of methanol extract of martynia annua seeds

\section{CONCLUSION}

The GC-MS analysis showed the presence of saturated and unsaturated free fatty acids,esters of fatty acids, flavones, alkaloid,aldehydes and ketones whereas in HPTLC different peaks at different UV-lights before and after derivatization were observed. Methanol extract of martynia annua seeds exhibited very good inhibition percentage (74\%) of DPPH scavenging activity at concentration $50 \mu \mathrm{g} / \mathrm{ml}$.

\section{AUTHORS CONTRIBUTIONS}

Ali Alrabie, Ola Basa?ar, and Inas al-qadsy carried out the experiment and wrote the manuscript. Dr. Mazahar Farooqui, the research supervisor conceived the original idea, supervised the project and corrected the scientific content of the manuscript.

\section{CONFLICT OF INTERESTS}

The authors have no conflict of interest

\section{REFERENCES}

1. Fabricant DS, Farnsworth NR. The value of plants used in traditional medicine for drug discovery. Environ Health perspect 2001;109 Suppl 1:69-75.

2. Revishankar B, Shukla VJ. Indian system of medicine: a brief profile. Afr J Tradit Complement Altern Med 2007:4:319-37.

3. Harish BB, Mohana LS, Saravana KA. Studies on phytochemical and anticonvulsant property of Martynia annua linn. Int J Phytopharmacol 2010;1:82-6.

4. Zarina A, Sumayya S, Shaista N. Antioxidant activities and phytochemical screening of Martynia annua seeds extract. Biosci Biotech Res Asia 2017;14:1363-9. 
5. Prakash P, Prabhakar S, Ramchndra G, Ashish G, Ajag S, Nitin N, et al. Formulation and evaluation of herbal effervescent granules incorporated with martynia annua extract. J Drug Discovery Ther 2013;1:54-7.

6. Eswaraiah MC, Eswarudu MM, Kumar KP, Kumar PS, Kumar TT. An overview on Martynia Annua L. Int J Pharm Res Dev 2013;5:113-8.

7. Ashwani KD, Bhawna C, Sanjeev KM. Martynia annua L.: a review on its ethnobotany, phytochemical and pharmacological profile. J Pharmacogn Phytochem 2013;1:135-40.

8. Renato B, Luciana GW, Gisely CL, Joao CPD. Quality control and TLC profile data on selected plants species commonly found in the Brazilian market. Rev Bras Farmacogn Braz J Pharmacogn 2012;22:1111-8.

9. Elangovan NM, Dhanarajan MS, Elangovan l. Preliminary phytochemical screening and HPTLC fingerprinting profile of leaf extracts of Moringa oleifera and Phyllanthus emblica. Int Res J Pharm Biosci 2015;2:32-40.

10. Shakila R, Ganesan R, Arul AS, Duraipandiyan V. Analytical and HPTLC studies on Coldenia Procumbens linn. whole plant. J Innovations Pharm Biol Sci 2017;4:28-35.

11. Calixto JB. Efficacy, safety, quality control, marketing and regulatory guidelines for herbal medicines (phytotherapeutic agents). Brazillian J Med Biol Res 2000;33:179-89.

12. Gayathri G, Saraswathy A, Vijayalakshmi K. HPTLC fingerprint profile of Bauhinia variegate Linn. leaves. Asian Pacific J Trop Dis 2012;2 Suppl 1:521-5.

13. Murugesan S, Bhuvaneswari S. HPTLC fingerprint profile of methanol extract of the marine red alga portieria hornemannii (Lyngbye) (Silva). Int J Adv Pharma 2016;5:61-5.

14. Shulammithi $R$, Sharanya $M$, Tejaswini R, Kiranmai M. Standardization and quality evaluation of herbal drugs. IOSR J Pharm Biol Sci 2016;11:89-100.

15. Anjoo K, Ajay KS. HPTLC fingerprint profile of extracts from dried aerial parts of Bryophyllum pinnatum in different solvents. Pharmacogn J 2010;2:24-31.

16. Pravin HN, Joseph K, Aruna J, Vilasrao K. Future trends in the standardization of herbal drugs. J Appl Pharm Sci 2012;2:38-44.

17. Reich E, Schibli A. High-performance thin layer chromatography for the analysis of medicinal plants. $1^{\text {st }} \mathrm{ed}$. Thieme medical publisher, Inc. The Americans, Ny; 2007.

18. Sreejayan N, Rao MN. Free radical scavenging activity by curcuminoids. Arzneimittelforschung 1996;46:169-71.
19. Chandana NDML, Jaya PRP, Kondammagari S, Borelli DPR, Nannepaga JS. Phytoconstituents profile of clitoria ternatea by GC-MS and its age-related anticholinergic activity against aluminum and restraint stress. Int Res J Pharm 2018;9:38-44.

20. Mustapha NA, Runner RTM. GC-MS analysis and preliminary antimicrobial activity of Albizia adianthifolia (Schumach) and Pterocarpus angolensis (DC). Medicines 2016;3:1-9.

21. Brinda C, Mohan KR. Evaluation of the antioxidant,antibacterial activity of ethanolic extract in the leaves of Combretum albidum and gas chromatography-mass spectrometry analysis. Asian J Pharm Clin Res 2016;9:325-9.

22. Rajendran P, Bharathidasan R, Sureshkumar K. GC-MS analysis of phyto-components in raw and treated sugarcane juice. Int J Curr Microbiol Appl Sci 2017;6:51-61.

23. Sheeba GD, Viswanathan P. GC-MC analysis of phytocomponents in Spermacoce articularis L. $f$. leaf. Res Pharm 2014;4:1-7.

24. Nisha, Pasaumarti BR. Gas chromatography-mass spectrometry analysis for identification of bioactive compounds in selected genotypes of Trigonella foenum-graecum L. Pharma Innovation 2018;7:929-39.

25. Padmashree MS, Roopa B, Ashwathanarayana R, Raja N. Antibacterial properties of Ipomoea staphylina roem and schult. Plant extracts with comparing its preliminary qualitative phytochemical and quantitative GC-MS analysis. Trop Plant Res 2018;5:349-69.

26. Ali A, Javaid A, Shoaib A. GC-MS analysis and antifungal activity of methanolic root extract of Chenopodium album against Scletotium rolfsii. Planta Daninha 2017;35:1-8.

27. Karuppasamy R, Veerabahu RM. GC-MS analysis of bioactive components of Myхорyrum serratulum A. W. hill (Oleacea). Int J Pharm Sci Rev Res 2016;38:30-5.

28. Vardhini SP, Sivaraj C, Himanshu R, Arumugam P. GC-MS, photochemical analysis and antioxidant activities of fruit pulp of Aegle marmelos (L.) correa. Eur J Biomed Pharm Sci 2018;5:569-74.

29. Konovalova O, Gergel E, Herhel V. GC-MS analysis of bioactive components of Shepherdia argentea (Pursh.) nutt. From Ukrainian. Pharma Innovation J 2013;2:7-12.

30. Siti K, Grace N, Irda F. Antioxidant activities from various extracts of different parts of Kelakai (Stenochlaena palustaris) grown in central Kalimantan-Indonesia. Asian J Pharm Clin Res 2016;9 Suppl 1:215-9. 